NASA/TM-2000-209891, Vol. 139

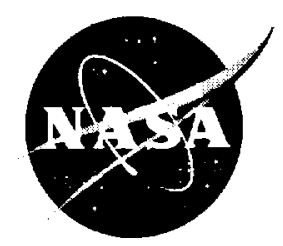

Technical Report Series on the Boreal Ecosystem-Atmosphere Study (BOREAS)

Forrest $G$. Hall and Shelaine Curd, Editors

\title{
Volume 139
}

BOREAS TE-5 Soil Respiration

Data

J. Ehleriinger, J.R. Brooks, and L. Flanagan

National Aeronautics and

Space Administration

Goddard Space Flight Center

Greenbelt, Maryland 20771 
The NASA STI Program Office ... in Profile

Since its founding, NASA has been dedicated to the advancement of aeronautics and space science. The NASA Scientific and Technical Information (STI) Program Office plays a key part in helping NASA maintain this important role.

The NASA STI Program Office is operated by Langley Research Center, the lead center for NASA's scientific and technical information. The NASA STI Program Office provides access to the NASA STI Database, the largest collection of aeronautical and space science STI in the world. The Program Office is also NASA's institutional mechanism for disseminating the results of its research and development activities. These results are published by NASA in the NASA STI Report Series, which includes the following report types:

- TECHNICAL PUBLICATION. Reports of completed research or a major significant phase of research that present the results of NASA programs and include extensive data or theoretical analysis. Includes compilations of significant scientific and technical data and information deemed to be of continuing reference value. NASA's counterpart of peer-reviewed formal professional papers but has less stringent limitations on manuscript length and extent of graphic presentations.

- TECHNICAL MEMORANDUM. Scientific and technical findings that are preliminary or of specialized interest, e.g., quick release reports, working papers, and bibliographies that contain minimal annotation. Does not contain extensive analysis.

- CONTRACTOR REPORT. Scientific and technical findings by NASA-sponsored contractors and grantees.
- CONFERENCE PUBLICATION. Collected papers from scientific and technical conferences, symposia, seminars, or other meetings sponsored or cosponsored by NASA.

- SPECIAL PUBLICATION. Scientific, technical, or historical information from NASA programs, projects, and mission, often concerned with subjects having substantial public interest.

- TECHNICAL TRANSLATION. English-language translations of foreign scientific and technical material pertinent to NASA's mission.

Specialized services that complement the STI Program Office's diverse offerings include creating custom thesauri, building customized databases, organizing and publishing research results ... even providing videos.

For more information about the NASA STI Program Office, see the following:

- Access the NASA STI Program Home Page at http://www.sti.nasa.gov/STI-homepage.html

- E-mail your question via the Internet to help@sti.nasa.gov

- Fax your question to the NASA Access Help Desk at (301) 621-0134

- Telephone the NASA Access Help Desk at (301) 621-0390

- Write to: NASA Access Help Desk NASA Center for AeroSpace Information 7121 Standard Drive Hanover, MD 21076-1320 
NASA/TM-2000-209891, Vol. 139

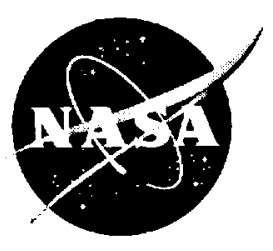

\section{Technical Report Series on the Boreal Ecosystem-Atmosphere Study (BOREAS)}

Forrest G. Hall and Shelaine Curd, Editors

\section{Volume 139}

\section{BOREAS TE-5 Soil Respiration}

\section{Data}

Jim Ehleriinger; University of Utah, Salt Lake City

J. Renee Brooks, University of South Florida, Tampa

Larry Flanagan, University of Lethbridge, Lethbridge, Alberta, Canada

National Aeronautics and

Space Administration

Goddard Space Flight Center

Greenbelt, Maryland 20771 
Available from:

NASA Center for AeroSpace Information

7121 Standard Drive

Hanover, MD 21076-1320

Price Code: A17
National Technical Information Service 5285 Port Royal Road Springfield, VA 22161 


\title{
BOREAS TE-5 Soil Respiration Data
}

\author{
Jim Ehleringer, J.Renee Brooks, Larry Flanagan
}

\section{Summary}

The BOREAS TE-5 team collected measurements in the NSA and SSA on gas exchange, gas composition, and tree growth. Soil respiration data were collected from 26-May-94 to 07-Sep-94 in the BOREAS NSA and SSA to compare the soil respiration rates in different forest sites using a LI-COR 6200 soil respiration chamber (model 6299). The data are stored in tabular ASCII files.

\section{Table of Contents}
1) Data Set Overview
2) Investigator(s)
3) Theory of Measurements
4) Equipment
5) Data Acquisition Methods
6) Observations
7) Data Description
8) Data Organization
9) Data Manipulations
10) Errors
11) Notes
12) Application of the Data Set
13) Future Modifications and Plans
14) Software
15) Data Access
16) Output Products and Availability
17) References
18) Glossary of Terms
19) List of Acronyms
20) Document Information

\section{Data Set Overview}

\subsection{Data Set Identification BOREAS TE-05 Soil Respiration Data}

\subsection{Data Set Introduction}

Soil respiration data were collected in the field in the BOReal Ecosystem-Atmosphere Study (BOREAS) Northern Study Area (NSA) and Southern Study Area (SSA) using a LI-COR 6200 portable photosynthesis system and a LI-COR soil respiration chamber (model 6299).

\subsection{Objective/Purpose}

The data were collected to compare the soil respiration rates in different forest sites in the BOREAS NSA and SSA. 


\subsection{Summary of Parameters}

- $\mathrm{CO}_{2}$ flux (positive respiration)

- soil temperature

- chamber $\mathrm{CO}_{2}$ concentration

- chamber air temperature

- chamber vapor pressure

\subsection{Discussion}

In the SSA, measurements were collected at the Old Jack Pine (OJP), Old Black Spruce (OBS), and Old Aspen (OA) sites. In the NSA, measurements were collected at the OJP, T6R5S TE Upland Black Spruce (UBS), and OA sites.

\subsection{Related Data Sets}

BOREAS TE-05 Leaf Gas Exchange Data

BOREAS TE-05 Leaf Carbon Isotope Data

BOREAS TE-05 Surface Meteorological and Radiation Data

\section{Investigator(s)}

\subsection{Investigator(s) Name and Title}

J.R. Ehleringer

University of Utah

Department of Biology

L.B. Flanagan

Carleton University

Department of Biology

\subsection{Title of Investigation}

Vegetation-Atmosphere $\mathrm{CO}_{2}$ and $\mathrm{H}_{2} \mathrm{O}$ Exchange Processes: Stable Isotope Analyses

\subsection{Contact Information}

\section{Contact 1:}

J. Renee Brooks

Department of Biology

University of South Florida

Tampa, FL 33620 USA

(813) $974-7352$

(813) 974-3263 (fax)

jrbrooks@chuma.cas.usf.edu

\section{Contact 2:}

Dr. Larry Flanagan

Department of Biological Sciences

University of Lethbridge

4401 University Drive

Lethbridge, Alberta

TIK 3M4, CANADA

(403) $380-1858$

(403) 329-2082 (fax)

larry.flanagan@uleth.ca 
Contact 3:

Shelaine Curd

Raytheon ITSS

Code 923

NASA GSFC

Greenbelt, MD 20771

(301) 286-2447

(301) 286-2039 (fax)

Shelaine.Curd@gsfc.nasa.gov

\section{Theory of Measurements}

Measurements were made using a LI-COR soil respiration chamber (model 6299) attached to a LI-COR 6200 portable photosynthesis system, an instrument that uses a dynamic, closed chamber technique. Theoretical details of the measurements and instruments can be obtained from the manufacturer: LI-COR, Inc., P.O. Box 4425 Superior Street, Lincoln, NE 68504, USA. Toll-free telephone 1-800-447-3576 (USA and Canada), telephone (402) 467-2819.

\section{Equipment}

\subsection{Sensor/Instrument Description}

\subsubsection{Collection Environment}

The equipment operated under ambient environmental conditions during the measurement periods. Please see BOREAS TE-05 Surface Meteorological and Radiation Data for specifics.

\subsubsection{Source/Platform}

None given.

\subsubsection{Source/Platform Mission Objectives}

The data were collected to compare the soil respiration rates in different forest sites.

\subsubsection{Key Variables}

$\mathrm{CO}_{2}$ Flux

Vapor Pressure

Soil Temperature

Air Temperature

\subsubsection{Principles of Operation}

Measurements were made using a LI-COR soil respiration chamber (model 6299) attached to a LI-COR 6200 portable photosynthesis system, an instrument that uses a dynamic, closed chamber technique.

\subsubsection{Sensor/Instrument Measurement Geometry \\ None given.}




\subsubsection{Manufacturer of Sensor/Instrument}

LI-COR, Inc.

P.O. Box 4425 Superior Street

Lincoln, NE 68504, USA

1 (800) 447-3576 (US \& Canada)

(402) 467-2819

\subsection{Calibration}

\subsubsection{Specifications}

None given.

\subsubsection{Tolerance}

None given.

\subsubsection{Frequency of Calibration}

None given.

\subsubsection{Other Calibration Information}

The infrared gas analyzer of the LI-COR 6200 portable photosynthesis system was calibrated using primary standard gas mixtures from Matheson Gas. These gas mixtures were compared to BOREAS project calibration standards.

\section{Data Acquisition Methods}

None given.

\section{Observations}

\subsection{Data Notes}

None given.

\subsection{Field Notes}

None given.

\section{Data Description}

\subsection{Spatial Characteristics}

\subsubsection{Spatial Coverage}

Samples were collected at NSA OJP, SSA OJP, SSA OBS, and NSA UBS in 1993 and all the sites in 1994. The North American Datum of 1983 (NAD83) coordinates for the sites are:

- $\quad$ NSA OJP flux tower site: Lat/Long $=55.927^{\circ} \mathrm{N}, 98.62^{\circ} \mathrm{W}$, Universal Transverse Mercator (UTM) Zone 14, N:6,197,997 E:523,501.

- SSA OJP flux tower site: Lat/Long $=53.916^{\circ} \mathrm{N}, 104.69^{\circ} \mathrm{W}$, UTM Zone $13, \mathrm{~N}: 5,951,000$ E:479,400.

- NSA OA canopy access tower site (auxiliary site number T2Q6A, BOREAS Experiment Plan, Version 3), Lat $/$ Long $=55.88^{\circ} \mathrm{N}, 98.67^{\circ} \mathrm{W}$. 
- $\quad$ SSA OA flux tower site: Lat/Long $=53.629^{\circ} \mathrm{N}, 106.197^{\circ} \mathrm{W}$, UTM Zone $13, \mathrm{~N}: 5,942,688$ E:420,874.

- $\quad$ NSA UBS canopy access tower site (auxiliary site number T6R5S, BOREAS Experiment Plan, Version 3), Lat $/$ Long $=55.70^{\circ} \mathrm{N}, 98.51^{\circ} \mathrm{W}$.

- $\quad$ SSA OBS flux tower site: Lat/Long $=53.985^{\circ} \mathrm{N}, 105.122^{\circ} \mathrm{W}$, UTM Zone $13, \mathrm{~N}: 5,981,904$ E:492,000.

\subsubsection{Spatial Coverage Map}

Not available.

\subsubsection{Spatial Resolution}

These data are point source measurements at the locations given.

\subsubsection{Projection}

Not applicable.

\subsubsection{Grid Description}

Not applicable.

\subsection{Temporal Characteristics}

\subsubsection{Temporal Coverage}

These data were collected over the period of 26-May-94 to 07-Sep-94.

\subsubsection{Temporal Coverage Map}

Not available.

\subsubsection{Temporal Resolution}

Each site was visited multiple times during the 1994 growing season.

\subsection{Data Characteristics}

\subsubsection{Parameter/Variable}

The parameters contained in the data files on the CD-ROM are:

Column Name

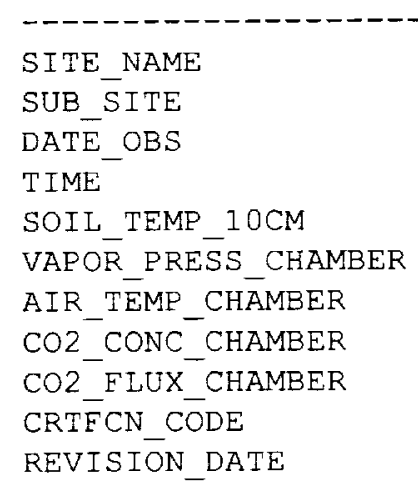




\subsubsection{Variable Description/Definition}

The descriptions of the parameters contained in the data files on the CD-ROM are:

\begin{tabular}{|c|c|}
\hline Column Name & Description \\
\hline SITE_NAME & $\begin{array}{l}\text { The identifier assigned to the site by BOREAS, } \\
\text { in the format SSS-TTT-CCCCC, where SSS identifies } \\
\text { the portion of the study area: NSA, SSA, REG, } \\
\text { TRN, and TTT identifies the cover type for the } \\
\text { site, } 999 \text { if unknown, and CCCCC is the identifier } \\
\text { for site, exactly what it means will vary with } \\
\text { site type. }\end{array}$ \\
\hline SUB_SITE & $\begin{array}{l}\text { The identifier assigned to the sub-site by BOREA } \\
\text { BOREAS, in the format GGGGG-IIIII, where GGGGG is } \\
\text { the group associated with the sub-site } \\
\text { instrument, e.g. HYDO6 or STAFE, and IIIII is the } \\
\text { identifier for sub-site, often this will refer to } \\
\text { an instrument. }\end{array}$ \\
\hline DATE_OBS & The date on which the data were collected. \\
\hline TIME. & $\begin{array}{l}\text { The Greenwich Mean Time (GMT) when the data were } \\
\text { collected. }\end{array}$ \\
\hline SOIL_TEMP_10CM & Soil temperature at $10 \mathrm{~cm}$ depth. \\
\hline VAPOR_PRES̄S_CHAMBER & Vapor pressure of the air in the chamber. \\
\hline AIR_TEMP_CHAMBER & The temperature of the air in the chamber. \\
\hline $\mathrm{CO} 2$ CONC_CHAMBER & The $\mathrm{CO} 2$ concentration in the chamber. \\
\hline CO2_FLUX_CHAMBER & The chamber $\mathrm{CO} 2 \mathrm{f} 1 \mathrm{ux}$. \\
\hline CRTÉCN_CODE & $\begin{array}{l}\text { The BOREAS certification level of the data. } \\
\text { Examples are CPI (Checked by PI), CGR (Certified } \\
\text { by Group), PRE (Preliminary), and CPI-??? (CPI } \\
\text { but questionable). }\end{array}$ \\
\hline REVISION_DATE & $\begin{array}{l}\text { The most recent date when the information in the } \\
\text { referenced data base table record was revised. }\end{array}$ \\
\hline
\end{tabular}

\subsubsection{Unit of Measurement}

The measurement units for the parameters contained in the data files on the CD-ROM are:

\begin{tabular}{|c|c|}
\hline Column Name & Units \\
\hline SITE_NAME & [none] \\
\hline SUB_SITE & [none] \\
\hline DATE_OBS & {$[D D-M O N-Y Y]$} \\
\hline TIME & [HHMMSS GMT] \\
\hline SOIL_TEMP_10CM & [degrees Celsius] \\
\hline VAPOR_PRESS_CHAMBER & [millibars] \\
\hline AIR_TEMP_CHAMMBER & [degrees Celsius] \\
\hline $\mathrm{CO}_{2}{ }^{-} \mathrm{CONC}$ CHAMBER & [parts per milition] \\
\hline CO2_FLUX_CHAMBER & [micromoles] [meter $r^{\wedge}-2$ ] [second $\left.{ }^{\wedge}-1\right]$ \\
\hline CRTFCN_CODE & [none] \\
\hline REVISION_DATE & {$[D D-M O N-Y Y]$} \\
\hline
\end{tabular}




\subsubsection{Data Source}

The sources of the parameter values contained in the data files on the CD-ROM are:

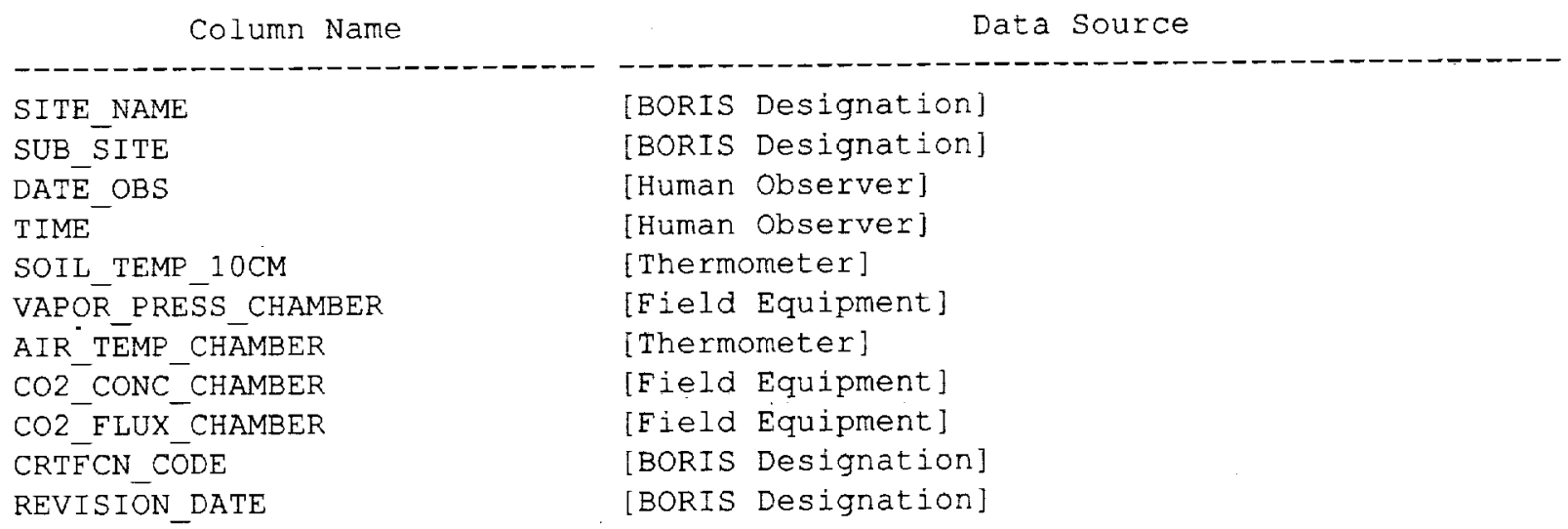

\subsubsection{Data Range}

The following table gives information about the parameter values found in the data files on the CD-ROM.

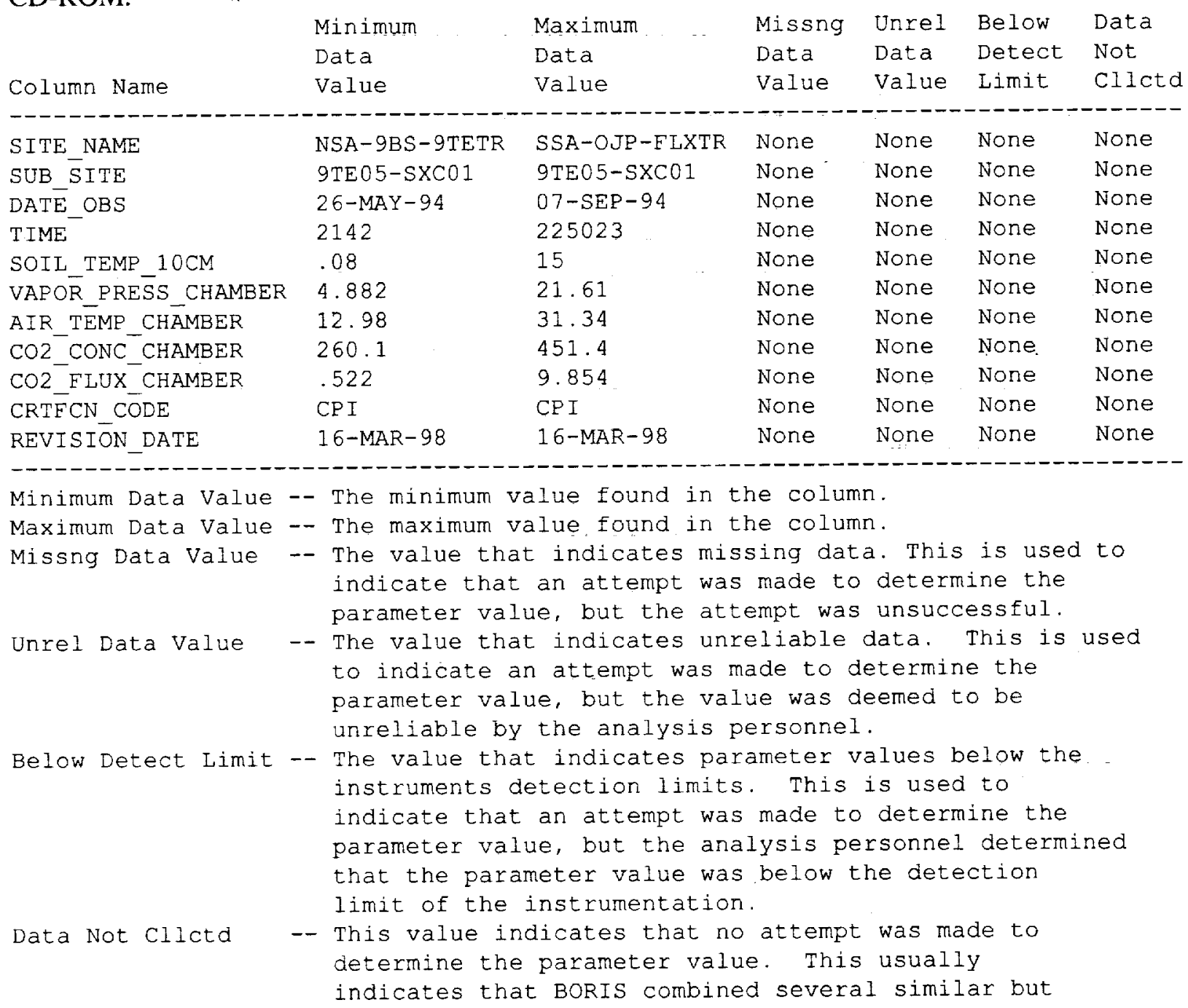




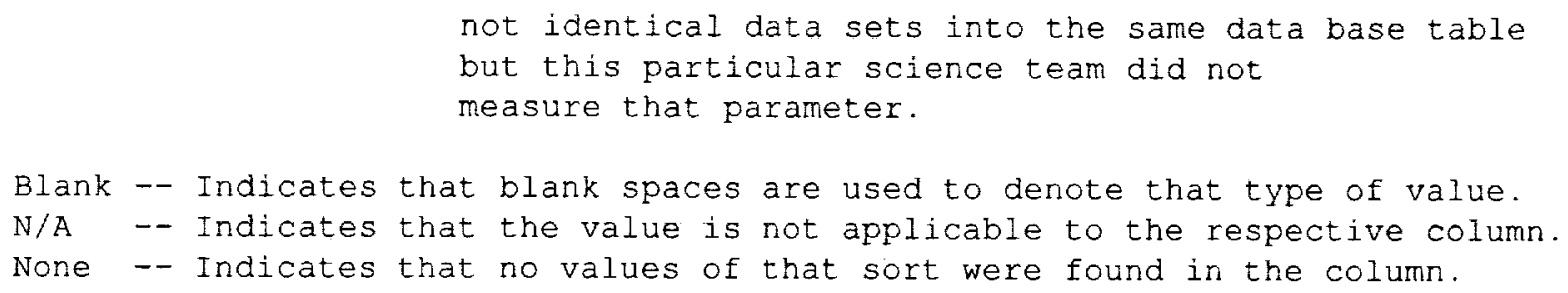

\subsection{Sample Data Record}

The following are wrapped versions of data record from a sample data file on the CD-ROM.

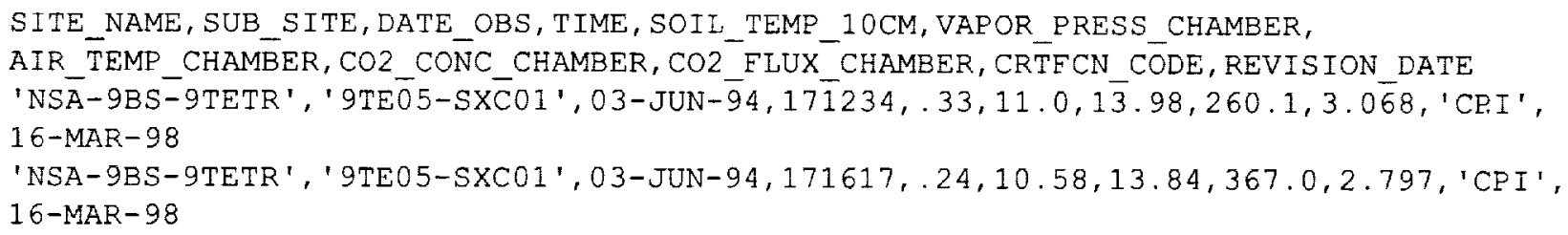

\section{Data Organization}

\subsection{Data Granularity}

The smallest unit of orderable data is data collected on one day at one site.

\subsection{Data Format(s)}

The Compact Disk-Read-Only Memory (CD-ROM) files contain American Standard Code for Information Interchange (ASCII) numerical and character fields of varying length separated by commas. The character fields are enclosed with single apostrophe marks. There are no spaces between the fields.

Each data file on the CD-ROM has four header lines of Hyper-Text Markup Language (HTML) code at the top. When viewed with a Web browser, this code displays header information (data set title, location, date, acknowledgments, etc.) and a series of HTML links to associated data files and related data sets. Line 5 of each data file is a list of the column names, and line 6 and following lines contain the actual data.

\section{Data Manipulations}

\subsection{Formulae}

None given.

\subsubsection{Derivation Techniques and Algorithms} None given.

\subsection{Data Processing Sequence}

\subsubsection{Processing Steps}

None given.

\subsubsection{Processing Changes \\ None given.}




\subsection{Calculations}

\subsubsection{Special Corrections/Adjustments}

None.

\subsubsection{Calculated Variables}

None.

9.4 Graphs and Plots None.

\section{Errors}

10.1 Sources of error

All known errors have been removed from the data.

10.2 Quality Assessment None given.

\subsubsection{Data Validation by Source} None given.

10.2.2 Confidence Level/Accuracy Judgment None given.

\subsubsection{Measurement Error for Parameters} None given.

\subsubsection{Additional Quality Assessments}

None given.

\subsubsection{Data Verification by Data Center}

Data were examined for general consistency and clarity.

\section{Notes}

\subsection{Limitations of the Data} None given.

\subsection{Known Problems with the Data} None given.

\subsection{Usage Guidance} None given.

\subsection{Other Relevant Information} None given. 


\section{Application of the Data Set}

These data can be used to compare soil respiration rates in different forest sites in the NSA and SSA.

\section{Future Modifications and Plans}

None given.

\section{Software}

\subsection{Software Description}

None given.

\subsection{Software Access}

None given.

\section{Data Access}

The soil respiration data are available from the Earth Observing System Data and Information System (EOSDIS) Oak Ridge National Laboratory (ORNL) Distributed Active Archive Center (DAAC).

\subsection{Contact Information}

For BOREAS data and documentation please contact:

ORNL DAAC User Services

Oak Ridge National Laboratory

P.O. Box 2008 MS-6407

Oak Ridge, TN 37831-6407

Phone: (423) 241-3952

Fax: (423) 574-4665

E-mail: ornldaac@ornl.gov or ornl@eos.nasa.gov

\subsection{Data Center Identification}

Earth Observing System Data and Information System (EOSDIS) Oak Ridge National Laboratory (ORNL) Distributed Active Archive Center (DAAC) for Biogeochemical Dynamics http://www-eosdis.ornl.gov/.

\subsection{Procedures for Obtaining Data}

Users may obtain data directly through the ORNL DAAC online search and order system [http://www-eosdis.ornl.gov/ and the anonymous FTP site [ftp://www-eosdis.ornl.gov/data/] or by contacting User Services by electronic mail, telephone, fax, letter, or personal visit using the contact information in Section 15.1.

\subsection{Data Center Status/Plans}

The ORNL DAAC is the primary source for BOREAS field measurement, image, GIS, and hardcopy data products. The BOREAS CD-ROM and data referenced or listed in inventories on the CD-ROM are available from the ORNL DAAC. 


\section{Output Products}

16.1 Tape Products

None.

\subsection{Film Products}

None.

\subsection{Other Products}

These data are available on the BOREAS CD-ROM series.

\section{References}

\subsection{Platform/Sensor/Instrument/Data Processing Documentation None.}

\subsection{Journal Articles}

Brooks, J.R., L.B. Flanagan, G.T. Varney, and J.R. Ehleringer. 1997. Vertical gradients in photosynthetic gas exchange characteristics and refixation of respired $\mathrm{CO}_{2}$ within boreal forest canopies. Tree Physiology 17: 1-12.

Newcomer, J., D. Landis, S. Conrad, S. Curd, K. Huemmrich, D. Knapp, A. Morrell, J. Nickeson, A. Papagno, D. Rinker, R. Strub, T. Twine, F. Hall, and P. Sellers, eds. 2000. Collected Data of The Boreal Ecosystem-Atmosphere Study. NASA. CD-ROM.

Sellers, P. and F. Hall. 1994. Boreal Ecosystem-Atmosphere Study: Experiment Plan. Version 1994-3.0, NASA BOREAS Report (EXPLAN 94).

Sellers, P. and F. Hall. 1996. Boreal Ecosystem-Atmosphere Study: Experiment Plan. Version 1996-2.0, NASA BOREAS Report (EXPLAN 96).

Sellers, P., F. Hall, and K.F. Huemmrich. 1996. Boreal Ecosystem-Atmosphere Study: 1994 Operations. NASA BOREAS Report (OPS DOC 94).

Sellers, P., F. Hall, and K.F. Huemmrich. 1997. Boreal Ecosystem-Atmosphere Study: 1996 Operations. NASA BOREAS Report (OPS DOC 96).

Sellers, P., F. Hall, H. Margolis, B. Kelly, D. Baldocchi, G. den Hartog, J. Cihlar, M.G. Ryan, B. Goodison, P. Crill, K.J. Ranson, D. Lettenmaier, and D.E. Wickland. 1995. The boreal ecosystem-atmosphere study (BOREAS): an overview and early results from the 1994 field year. Bulletin of the American Meteorological Society. 76(9):1549-1577.

Sellers, P.J., F.G. Hall, R.D. Kelly, A. Black, D. Baldocchi, J. Berry, M. Ryan, K.J. Ranson, P.M. Crill, D.P. Lettenmaier, H. Margolis, J. Cihlar, J. Newcomer, D. Fitzjarrald, P.G. Jarvis, S.T. Gower, D. Halliwell, D. Williams, B. Goodison, D.E. Wickland, and F.E. Guertin. 1997. BOREAS in 1997: Experiment Overview, Scientific Results and Future Directions. Journal of Geophysical Research 102(D24): 28,731-28,770.

\subsection{Archive/DBMS Usage Documentation} None. 


\section{Glossary of Terms}

None.

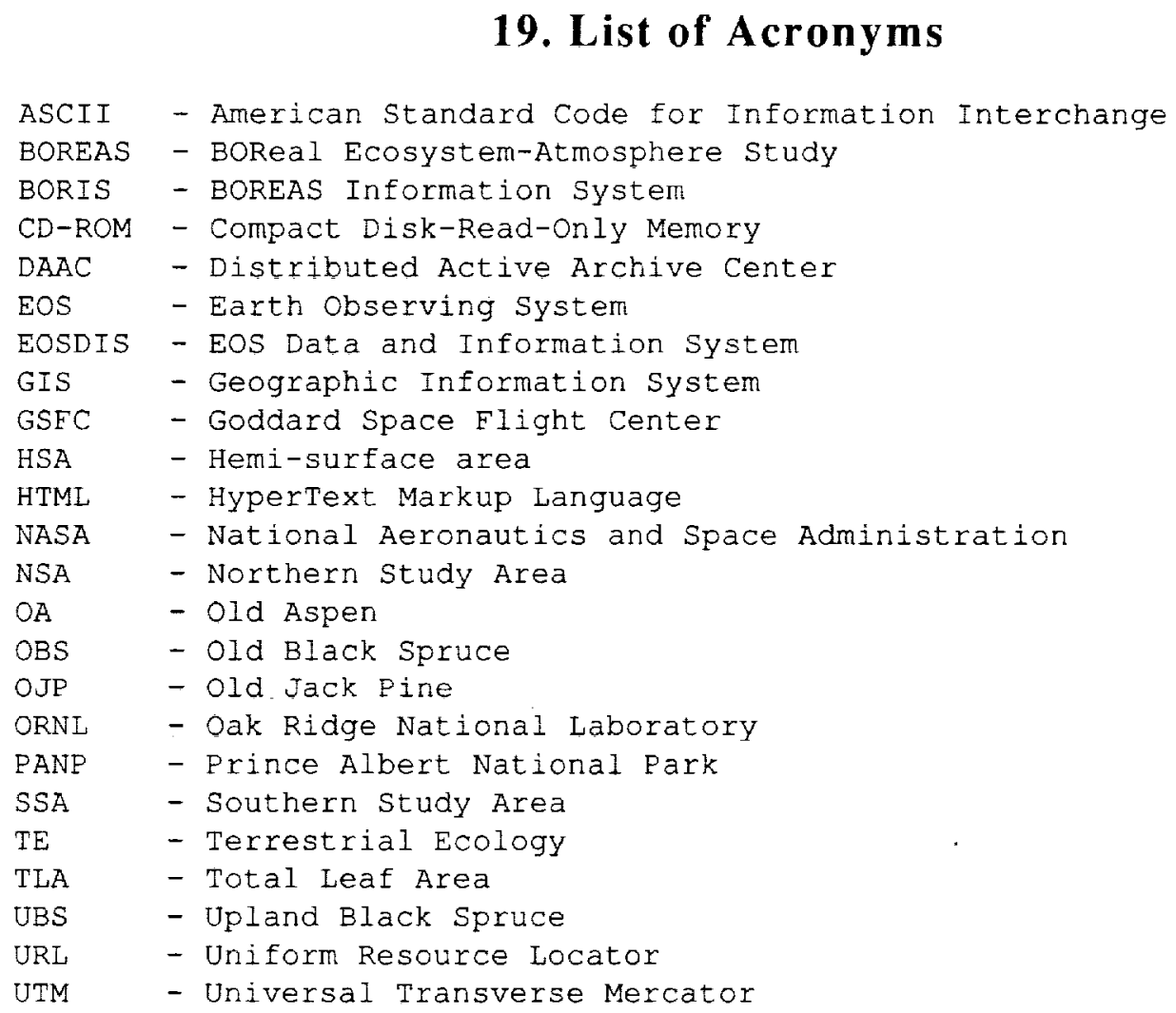

\section{Document Information}

\subsection{Document Revision Date}

Written : 10-Jun-1997

Last Updated: 27-May-1999

\subsection{Document Review Date(s)}

BORIS Review: 10-Jun-1997

Science Review:

\subsection{Document}

\subsection{Citation}

When using these data, please contact one of the investigators listed in Section 2.3 as well as citing relevant papers in Section 17.2. 
If using data from the BOREAS CD-ROM series, also reference the data as:

Ehleringer, J.R. and L.B. Flanagan, "Vegetation-Atmosphere $\mathrm{CO}_{2}$ and $\mathrm{H}_{2} \mathrm{O}$ Exchange Processes: Stable Isotope Analyses." In Collected Data of The Boreal Ecosystem-Atmosphere Study. Eds. J.

Newcomer, D. Landis, S. Conrad, S. Curd, K. Huemmrich, D. Knapp, A. Morrell, J. Nickeson, A. Papagno, D. Rinker, R. Strub, T. Twine, F. Hall, and P. Sellers. CD-ROM. NASA, 2000.

Also, cite the BOREAS CD-ROM set as:

Newcomer, J., D. Landis, S. Conrad, S. Curd, K. Huemmrich, D. Knapp, A. Morrell, J.

Nickeson, A. Papagno, D. Rinker, R. Strub, T. Twine, F. Hall, and P. Sellers, eds. Collected Data of The Boreal Ecosystem-Atmosphere Study. NASA. CD-ROM. NASA, 2000.

\subsection{Document Curator}

\subsection{Document URL}


Davis Highway, Suite 1204, Arlington, VA 22202-4302, and to the Office of Management and Budget, Paperwork Reduction Project (0704-0188). Washington, DC 20503.

\begin{tabular}{l|l|l} 
1. AGENCY USE ONLY (Leave blank) & 2. REPORT DATE & 3. REPORT TYPE AND DATES COVERED
\end{tabular}

October 2000

Technical Memorandum

4. TITLE AND SUBTITLE

Technical Report Series on the Boreal Ecosystem-Atmosphere Study (BOREAS)

BOREAS TE-5 Soil Respiration Data

6. AUTHOR(S)

Jim Ehleriinger, J. Renee Brooks and Larry Flanagan

Forrest G. Hall and Shelaine Curd, Editors

7. PERFORMING ORGANIZATION NAME(S) AND ADDRESS (ES)

Goddard Space Flight Center

Greenbelt, Maryland 20771

5. FUNDING NUMBERS

923

RTOP: $923-462-33-01$

National Aeronautics and Space Administration

Washington, DC 20546-0001

10. SPONSORING / MONITORING AGENCY REPORT NUMBER

TM-2000-209891

Vol. 139

11. SUPPLEMENTARY NOTES

J. Ehleriinger: University of Utah, Salt Lake City; J.R. Brooks: University of South Florida, Tampa;

L. Flanagan: University of Lethbridge, Lethbridge, Alberta, Canada; C. Curd: Raytheon ITSS, NASA Goddard Space Flight Center. Greenbelt. Maryland 12a. DISTRIBUTION / AVAILABILITY STATEMENT

Unclassified-Unlimited

Subject Category: 43

Report available from the NASA Center for AeroSpace Information,

7121 Standard Drive, Hanover, MD 21076-1320. (301) 621-0390.

13. ABSTRACT (Maximum 200 words)

The BOREAS TE- 5 team collected measurements in the NSA and SSA on gas exchange, gas composition, and tree growth. Soil respiration data were collected from 26-May-94 to 07-Sep-94 in the BOREAS NSA and SSA to compare the soil respiration rates in different forest sites using a LI-COR 6200 soil respiration chamber (model 6299). The data are stored in tabular ASCII files.

\begin{tabular}{|c|c|c|c|}
\hline \multicolumn{3}{|c|}{$\begin{array}{l}\text { 14. SUBJECT TERMS } \\
\text { BOREAS, terTestrial ecology, soil respiration. }\end{array}$} & $\begin{array}{l}\text { 15. NUMBER OF PAGES } \\
13\end{array}$ \\
\hline & & & 16. PRICE CODE \\
\hline $\begin{array}{l}\text { 17. SECURITY CLASSIFICATION } \\
\text { OF REPORT } \\
\text { Unclassified }\end{array}$ & $\begin{array}{l}\text { 18. SECURITY CLASSIFICATION } \\
\text { OF THIS PAGE } \\
\text { Unclassified }\end{array}$ & $\begin{array}{l}\text { 19. SECURITY CLASSIFICATION } \\
\text { OF ABSTRACT } \\
\text { Unclassified }\end{array}$ & $\begin{array}{l}\text { 20. LIMITATION OF ABSTRACT } \\
\text { UL }\end{array}$ \\
\hline
\end{tabular}

